\title{
DIASPORA NETWORKS AND THE CONSUMPTION OF NOSTALGIC PRODUCTS AMONG ROMANIAN MIGRANTS IN GERMANY
}

\author{
Andrei Bundas \\ Faculty of Economic Sciences, University of Oradea, Oradea, Romania \\ andrei.bundas@gmail.com
}

\begin{abstract}
Statistics show that cross-national immigration represents one of the fastest growing global trends. Researchers have revealed that immigration is a transnational process with immigrants maintaining ties across the sending and receiving locations, and acting as a bridge between their countries of destination and origin. Research has also revealed the economic link created by the diaspora between the countries of origin and destination with two main components: the remittances sent to families and the consumption of home origin goods, also defined by scholars as ethnic products, nostalgic products or nostalgia products. During the period 2010-2015, the Romanian diaspora had the world's second fastest average annual growth rate. In the same period, Germany became one of the premier destinations for Romanian migration. An empirical study was organized in Germany in the period June - August 2017. The study is based on a regional survey of 124 subjects belonging to the Romanian community in Germany in four Bavarian cities. Four hypotheses have been advanced with the purpose of evaluating the level of demand for home origin products among Romanian migrants, the sources of supply, the level of expenditures and the motivational factors. The findings show that Romanian migrants in Germany manifest an important interest in and demand for home origin country goods; they spend 420 EUR yearly on ethnic products and their consumption motivation is strongly related to the products' special tastes and characteristics. Most of the products are obtained through local ethnic stores. The study's results also reveal important similarities between the nostalgic product consumption habits of Romanian migrants in Germany and those of South American migrants in the U.S. The study's findings are relevant for both the literature and for the Romanian companies, especially the ones active in the food and drink sector.
\end{abstract}

Keywords: Romanian diaspora, Romanian migrants, ethnic products, nostalgic products.

JEL classification: F22, J15.

\section{Introduction}

Migration represents one of the fastest growing global trends, reaching 244 million in 2015, up from 222 million in 2010 and 173 million in 2000 (U.N., Department of Economic and Social Affairs, 2016).

According to the 2015 U.N. International Migration Report, the Romanian diaspora had the world's second fastest average annual growth rate, 7.3 percent per annum, during the period 2010-2015 (U.N., 2016: 21). More than 3 million Romanians were residents in EU countries as of January 1, 2017 (EUROSTAT, 2018:13). The main emigration countries for Romanians are Italy, Spain, Germany and England (Sandu 2010; Drăgulin, 2012; Sandu, 2018).

Such a significant number of emigrants have important socio-economic implications for Romania. Apart from the negative impact of migration, the literature also investigates some positive implications of the phenomenon. One is represented by the remittances sent by migrants to their families. The yearly amount of remittances sent home by Romanian 
migrants has fluctuated between $\$ 3$ billion and $\$ 4$ billion in the last few years with researchers revealing the multiple benefits they have brought to Romanian society and to the economy (Herban, 2015; Anghelache, Nita and Badiu, 2017).

This paper investigates another outcome of migration: the consumption of Romanian products among the Romanian migrants in Germany. The consumption of home products is defined by most of the scholars as consumption of ethnic products (Pires and Stanton 2005; Mehmood, Jamal and Sriram 2015). There are also original definitions such as "nostalgic products" used by Orozco (2008a; 2008c; 2015) or "nostalgia products" used by Newland and Taylor (2010).

The literature review shows a scarcity in the research of economic implications of diasporas in general and regarding the consumption of ethnic products among migrants in particular. The situation is similar in this respect as it regards the Romanian diaspora.

Under these circumstances, the current study objective has been to fill this gap by investigating the main traits of home country goods consumption among Romanian migrants in Germany.

Statistics indicate that a significant increase of Romanian migration to Germany has occurred in recent years as shown in the table below:

Table 1: Evolution of Romanian residents in Germany

\begin{tabular}{|c|c|c|c|c|c|c|c|c|}
\hline Year & $\mathbf{2 0 1 0}$ & $\mathbf{2 0 1 1}$ & $\mathbf{2 0 1 2}$ & $\mathbf{2 0 1 3}$ & $\mathbf{2 0 1 4}$ & $\mathbf{2 0 1 5}$ & $\mathbf{2 0 1 6}$ & $\mathbf{2 0 1 7}$ \\
\hline $\begin{array}{c}\text { No of } \\
\text { residents }\end{array}$ & 126,536 & 159.222 & 205,026 & 267,398 & 355,343 & 452,718 & 533,660 & 622,780 \\
\hline
\end{tabular}

Source: own data processed based on the data provided by the Federal Statistical Office of Germany (DeStatis - Statistisches Bundesmat).

\section{Literature review}

The economic implications of migration are generating an increasing interest among scholars. Many researchers are investigating the transnational links generated by the diaspora between countries of destination and countries of origin (Girma and Yu, 2000; Javorcik et al., 2011; Hernandez, 2014; Elo, 2014).

Until recently most of the scholars' attention was concentrated on the effects induced by migration on destination countries. Researchers have since re-conceptualized the immigration process, revealing the fact that immigration is a transnational process with immigrants maintaining ties across the sending and receiving locations and acting as a bridge between their countries of destination and origin, diminishing the cultural, economic and institutional distances and facilitating investment in both directions-to and from their country of origin (Hernandez, 2014).

In her paper, "Diaspora networks in international business and transnational entrepreneurship - A literature review", Maria Elo's emphasis is on the growing importance of diaspora networks nowadays and their impact on multiple aspects of economic activity such as investment, entrepreneurship, innovation, expansion, internationalization and the creation of international businesses (Elo, 2014).

The researchers of the topic are often quoting Hernandez (2014). Using data from a sampling of foreign subsidiaries established in the U.S. between 1998 and 2003 by firms from 27 countries, Hernandez (2014) analysed the relationship between immigrants and the foreign expansion of organizations from their home countries. The results confirmed the assumptions, such as "the probability of locating operations and surviving in a state increases with the concentration of same-nationality immigrants" (Hernandez, 2014). The explanation lies in the fact that common country bonds with immigrants create a channel of knowledge between firms interested in expansion and the co-nationals from that country. It highlights the fact that this mechanism is particularly important for companies on their first 
attempt in international markets and which lack experience and information regarding the country targeted for expansion. Such inexperienced firms will target those places with a significant concentration of co-national immigrants. It has also been observed that experienced firms are not as sensitive to these aspects and do not show the same level of interest in using a similar strategy (Hernandez, 2014).

Javorcik et al. (2011) investigates in a similar manner the effect of diaspora networks on foreign direct investment. The premise of the paper is that international transactions are plagued not only by trade barriers but also by informal trade barriers such as difficulties accessing information about the potential markets. The authors show that direct investment generally requires "a long-term focus and interactions with diverse group of economic agents from suppliers, workers to government officials. The investor needs to have a detailed knowledge of the consumer, labour and input markets as well as legal and regulatory regimes in the host country" (Javorcik et al. 2011). The data analysis suggests that the presence of migrants in the U.S. has an effect on increases of foreign direct investment in their country of origin. It is observed to have a stronger effect for skilled migrants having at least a college education. In regards to the economic effect, the results indicate that a one percent increase in the migrant stock is associated with a 0.3 percent increase in the foreign direct investment stock (Javorcik et al. 2011).

Another important research approach is the one investigating the trade effect generated by migration in the country of destination and the country of origin (Dunlevy and Hutchinson, 1999; Genc et al., 2011; Kusum, 2012). Genc et al (2011) shows that immigration boosts trade between sending and receiving countries, respectively, "an increase in the number of immigrants by 10 percent increases the volume of trade by about 1.5 percent" (Genc et al., 2011).

Another approach belongs to Dunlevy and Hutchinson (1999) who analyze the connections the diaspora creates between the country of adoption and the country of origin from the point of view of the knowledge the diasporans hold about the market and the products of the country of origin as well as the acquaintances they acquire regarding the country of adoption. Dunlevy and Hutchinson have identified three main hypotheses by which immigrants become factors of proximity and connection between the home and adoption markets. First, they refer to the fact that immigrants have a good knowledge of the products of the country of origin, such as the taste in the case of foodstuffs or the functionality of specific products. Another proximity offered by migrants is their ability to perceive the opportunities that products in one of the markets have on the other market in terms of price or specific product features. The third characteristic refers to the positive effect induced to trade by ethnic networks. The knowledge of language, culture and customs of the home country gives migrants an important advantage in initiating and developing business relationships with their nationals. Ultimately, the presence of migrants in the country of adoption creates a critical mass of consumers that favors the initiation of imports of products into the country of adoption (Dunlevy and Hutchinson, 1999).

Kumar and Steenkamp (2013a, 2013b) have a similar approach. They consider that the presence of the co-national in a foreign country represents a "beachhead" for the companies from home countries, a very important support for establishing their products and brands in developed markets and also providing opportunities for promotion among the mainstream consumers.

A very important contribution to the literature was brought on by Manuel Orozco in his vast research activity. In his vision, an outcome of continuing migration is the formation of transnational communities (Orozco, 2005b). He defines these communities as "groups or families that maintain relations and connections with both their home and host societies" (Orozco, 2005b: 24). In this context, Orozco talks about the significant impact generated by this linkage on the receiving countries' economies. He identified four typical economic links 
of immigrants with their home country: "family remittance transfers, demand of goods and services, such as telecommunication, consumer goods or travel, capital investment and charitable donations to philanthropic organizations raising funds for the home country's community" (Orozco, 2005b: 25).

Orozco concludes that remittances and the consumption of home products have the highest impact on home countries' economies (Orozco 2015).

There is significant literature treating the remittances and their outcomes but few, almost none, address and analyze the home product consumption among immigrants.

The consumption of home country goods is most often defined by scholars as consumption of "ethnic products" (Pires and Stanton 2005; Mehmood, Jamal and Sriram, 2015). Orozco uses an original term, "nostalgic products", while Newland, K. and Taylor, C. (2010), use an adaptation such as "nostalgia products" (Newland and Taylor, 2010).

In 2008 Orozco published one of his most representative papers entitled "Trends in Migrant Demand for Home-Country Goods", a study regarding the demand of nostalgic products among 12 ethnic groups in the U.S. (Orozco, 2008a: 1). According to Newland and Taylor (2010), it was the first research of this kind in the literature.

Orozco (2008a) talks about the long tradition among immigrants of consuming home country goods. At the same time, he considers it a "practice that serves as an affirmation of one's sense of belonging to that which they call homeland". It has been observed that the intensification of the migration process on the global scale stimulates the development of transnational networks and increases the chances for migrants to adapt their life by adopting social and economic practices specific to their countries of origin (Orozco, 2008a: 2). One important objective of Orozco's research is to analyse the level of demand for home country goods. Orozco concludes that a large majority, about 90 percent of migrants in the U.S., consume on a regular basis home country goods, or ethnic goods, especially food products (Orozco, 2008c: 3). However, there are some exceptions, such as the case of the Cuban community, in which U.S. prohibition of imports from Cuba presents an obstacle (Orozco, 2015). In the case of the Albanian community, its limited number of members in the U.S. and trading difficulties with the homeland of Albania reduce the level of consumption of home country goods among community members (Orozco, 2015).

An important finding regards the average annual migrants' expenses on ethnic products of nearly one thousand U.S. dollars or more (Orozco, 2008a: 2). Orozco discusses the significant amounts spent by migrants to buy ethnic products and the positive effects induced to home country economies.

An interesting addressed question concerns the reasons why the migrants buy home country goods or nostalgic goods. The findings show that the majority replied that it is simply because "they like it"; according to another important group, it is because the product "is unique to their country" (Orozco, 2008a: 2).

Orozco's research has also targeted the supply chain of ethnic products, a network of distributors that buys the ethnic products from various countries and supplies them to ethnic retailers, most of them small, minority-owned, neighborhood ethnic stores. The ethnic entrepreneurs play an important role in this respect, being best positioned to understand their co-nationals' needs and to develop collaborations with home country producers and distributors (Jamal and Sriram 2015).

Orozco's research brings an important contribution to the literature. He has published a vast number of reports and research articles about immigrants and the economic manifestations of their linkage with the home countries, offering valuable information on the topic. He has also offered a valuable model and methodology for researchers interested in studying the topic. The current research has used much of Orozco's methodology as a research model. The literature review has also revealed that the research on Romanian migration is relatively well represented in the field of sociology. 
Despite the fact that the literature review suggests that economic-related research articles on Romanian migration are relatively limited, the figures suggest an increasing interest in the subject among scholars.

In this respect, it is worth mentioning Dinu, Grosu and Saseanu (2015), which has investigated the entrepreneurial manifestation potential of Romanian immigrants in Andalusia, Spain. The research identified some obstacles, which block or discourage the entrepreneurial manifestation. It also reveals more oriented manifestations based on gender or age.

Croitoru (2013) analyses in a similar manner the relationship between migration and entrepreneurship. In his research, he analyses how individuals' experience of international migration affects their propensity to entrepreneurial behaviours. He also highlights some of the features of Romanian migration to Austria.

Saseanu, Petrescu and Zgură (2011) contribute to the literature through an investigation on a grocery store specialized in selling Romanian products in Andalusia, Spain.

From a different perspective, Saseanu and Petrescu (2011) investigated the potential connections between migration and food consumption habits of Romanian immigrants in Andalusia, Spain. Their research revealed that the length of residence is positively correlated to the changes in food consumption after migration, while age is negatively correlated.

The complexity of the Romanian migration phenomenon and its profound implications invite further research and investigation.

\section{Data and research methodology}

In the current study, the empirical method has been used with application of a survey research design combined with the participant observation method.

The survey's subjects have been selected from four German cities, Ingolstadt, Augsburg, Munich and Fürth near Nuremberg in the period June - August 2017.

The survey's questionnaire contained more than thirty questions combining closed and open questions, structured in three parts. In the first part the questions regarded personal, family and demographic attributes. In the second part, the questions referred to the habits of consumption of Romanian origin products among subjects. The questionnaire's third part regarded the subjects' social contacts and their level of integration in the German society. The survey sample size included 124 subjects who filled out the questionnaires with the support of the interviewer, of which 50 were females. 56 questionnaires were completed in Ingolstadt, 8 in Augsburg, 27 in Munich and 33 in Fürth.

The subjects were selected using the convenient sampling from areas frequented by Romanian migrants, such as Romanian ethnic stores, cultural and religious events held in Ingolstadt, and the proximity of the Romanian consulate in Munich.

The subjects selected from places others than the proximity of Romanian ethnic stores and not directly related with the intent to purchase products having Romanian origin are considered "independent subjects".

Many of the questionnaire's questions addressed the study's objective, which is to identify the main traits of home country goods consumption among Romanian migrants in Germany. In addition, a significant number of questions are similar to the ones used in Orozco's research, thus enabling the comparison between the findings.

Orozco's research suggests that the consumption of nostalgic products among the members of analyzed ethnic communities in the U.S. varies between $40 \%$ and $90 \%$ or more. A low consumption level is associated with small communities, like the Albanians in the U.S., or ethnic communities whose home countries have the disadvantage of facing U.S. import sanctions, such as in the case of Cuba. 
Under these circumstances, we can differentiate less developed ethnic markets in the case of ethnic communities with less than $50 \%$ of its members buying home origin goods, and mature ethnic markets in the case of ethnic communities whose members consume home origin goods in the proportion of $90 \%$ or more.

Therefore, the first hypothesis refers to the percent of Romanian residents in Germany that regularly consume Romanian products:

$\mathrm{H} 1$ : At least $50 \%$ of Romanian residents in Germany consume Romanian origin products.

Orozco's research indicates that the yearly amount spent on products varies between $\$ 400$ and $\$ 1100$. Therefore, the question arises regarding the average amount spent on buying ethnic products by Romanian residents in Germany:

H2: The average amount spent by Romanian residents in Germany to buy ethnic products is more than $\$ 400$, the equivalent of approximately $€ 345$.

The literature suggests that most of the ethnic products are available through local ethnic grocery stores. This led to the third aspect to be investigated:

H3: More than $50 \%$ of the nostalgic products purchased by the Romanian consumers in Germany are from local Romanian ethnic grocery stores.

Finally, it is essential to understand the motivations that lie behind the decision to purchase home origin goods:

$\mathrm{H} 4$ : The main trigger for nostalgic product consumption among Romanian residents in Germany is related to the products' Romanian origin.

\section{Results}

Secondary data, such as websites of grocery stores specialized in selling Romanian products and multi-ethnic stores that have Romanian products in their portfolio, as well as details offered by Romanian producers and exporters of food and drink products, suggests the existence of an important demand and offering of Romanian products in Germany. In addition, the observations made on the Romanian community in Ingolstadt sustain this assumption.

Relevant results have been obtained by analysing the data collected through the survey. For estimating the percent of Romanian residents in Germany that regularly consume Romanian origin products, only the data collected from the independent subjects was selected, processed and analyzed.

Independent subjects have been selected from locations not directly related with Romanian ethnic stores. The results are presented in the table below:

Table 2: Purchase intention concerning home country goods (percentage)

\begin{tabular}{|c|c|c|c|}
\hline \multicolumn{2}{|c|}{ *Subjects sample 1 } & \multicolumn{2}{c|}{${ }^{* \star}$ Subjects sample 2 } \\
\hline Buy & Not Buy & Buy & Not Buy \\
\hline 84 & 16 & 79 & 21 \\
\hline
\end{tabular}

Source: Field Survey, 2017

*subjects selected during cultural and religious events organized in Ingolstadt June - July 2017, n=51

${ }^{* *}$ subjects selected in the proximity of the Romanian Consulate in Munich in August 2017, $n=14$

Taking into consideration the data from both independent samples, the overall purchase intention among Romanian residents was calculated as presented in Table number 3. 
Table 3: Purchase intention concerning home country goods (percentage)

Source: Field Survey, 2017

\begin{tabular}{|c|c|}
\hline Buy & Not Buy \\
\hline 81 & 19 \\
\hline
\end{tabular}

Secondly, the data regarding average amounts spent by Romanian migrants on buying "nostalgic products" in Germany has been processed and analysed. The findings are presented in the table below:

Table 4: Expenditure of Romanian ethnic products bought in Germany

\begin{tabular}{|c|c|c|c|c|c|}
\hline $\begin{array}{c}\text { Number of } \\
\text { persons in } \\
\text { household }\end{array}$ & $\begin{array}{c}\text { Times } \\
\text { bought } \\
\text { per } \\
\text { month }\end{array}$ & $\begin{array}{c}\text { Monthly } \\
\text { expenses / } \\
\text { household } \\
(\boldsymbol{(})\end{array}$ & $\begin{array}{c}\text { Yearly } \\
\text { expenses / } \\
\text { household } \\
(\boldsymbol{(})\end{array}$ & $\begin{array}{c}\text { Yearly } \\
\text { expenses / } \\
\text { household } \\
\text { member } \\
(\boldsymbol{\epsilon})\end{array}$ & $\begin{array}{c}\text { Yearly } \\
\text { expenses / } \\
\text { household } \\
\text { member } \\
*(\$)\end{array}$ \\
\hline 2.5 & 2.3 & 87.9 & 1054.4 & 420.4 & 498.3 \\
\hline
\end{tabular}

Source: Field Survey, 2017

*European Central Bank exchange rate at 31.08.2017: 1 EUR $=1.1825$ USD

Another relevant finding revealed by the survey's data refers to the average purchase sessions per month of 2.3, approximately one session at two week intervals.

Thirdly, in regards to the distribution network of Romanian products in Germany, as expected most of the subjects indicated the Romanian ethnic grocery stores as the main source of supply:

Table 5: Sources of supply of ethnic products among Romanian migrants in Germany (percentage)

\begin{tabular}{|c|c|c|c|}
\hline & $\begin{array}{c}\text { Romanian ethnic } \\
\text { grocery stores }\end{array}$ & $\begin{array}{c}\text { Multi-ethnic grocery } \\
\text { stores }\end{array}$ & German retailers \\
\hline & 74 & 13 & 13 \\
\hline
\end{tabular}

Source: Field Survey, 2017

The observations made at Ingolstadt revealed the fact that a Romanian ethnic grocery store functioned in the area until 2014 when it closed. The discussions with Romanian consumers suggested that the store had uncompetitive prices, which made it unprofitable. Afterwards, the main source of home origin goods for the Romanians in the Ingolstadt area was represented by three multi-ethnic grocery stores offering a range of Russian, Polish, Romanian and other East European products. Some of the Romanians from the area would purchase Romanian products during their travels to neighboring cities Munich or Nuremberg. A traditional Romanian restaurant was also functioning in the city of Ingolstadt. The discussions with members of the Romanian community in Ingolstadt also revealed ethnic entrepreneurial plans for opening a grocery store specialized in selling Romanian products or a second Romanian traditional restaurant in the area.

Finally, one of the key questions addressed to the survey's subjects regarded the reason why they buy Romanian products. It was presented as an open question that offered subjects the opportunity to use their own words to answer. It is notable that there was a big variety of answers and reasons expressed by the subjects regarding the consumption of home country goods. Following the model used by Orozco (2008a) on this topic, the answers offered by subjects have been grouped into five categories:

- Habit. I used to consume them in my home country

- Sense of attachment to the home country 
- The products are unique to my home country

- Quality of products is higher than other products

- I like them; I like their taste

Once the subjects' answers were sorted into the five categories, the totals were calculated for each category. The results are presented in the figure below:

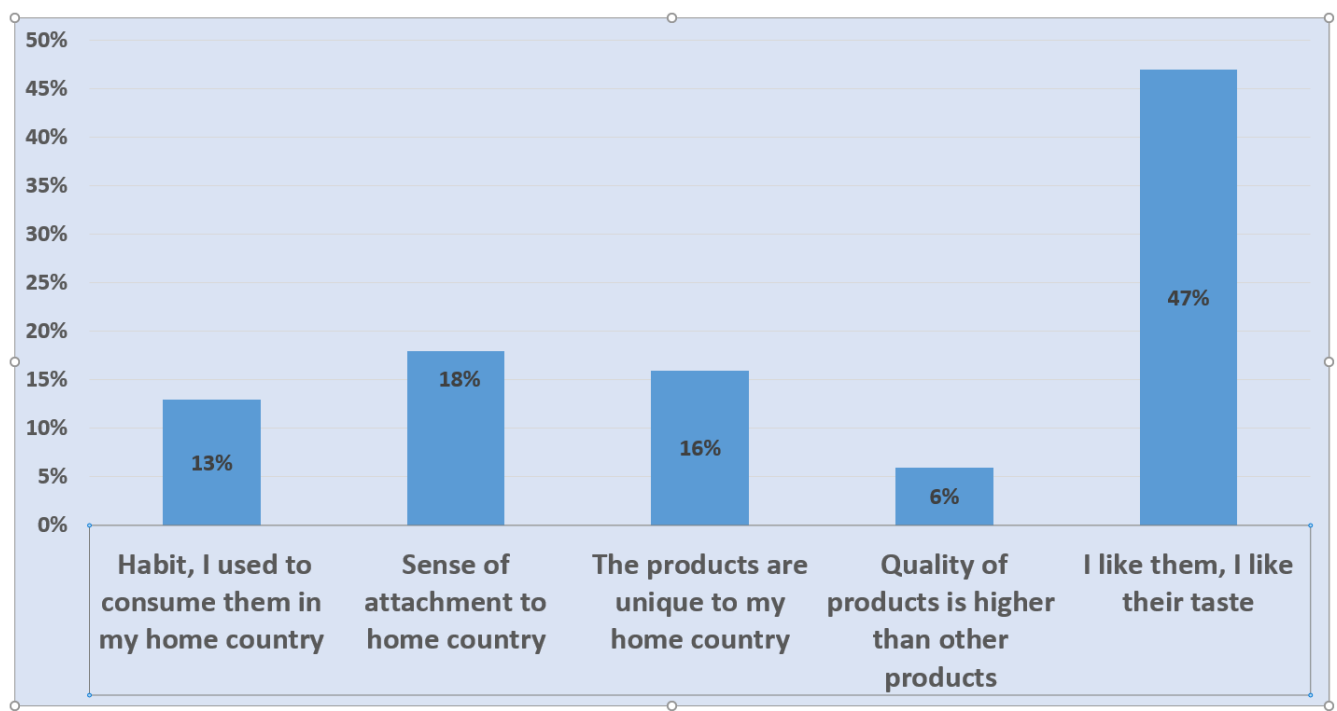

Figure 1: Romanian migrants' motivations to buy ethnic products in Germany Source: Field Survey, 2017

In the case of subjects that replied negatively to the question regarding the purchasing of Romanian products, it would have been useful to address a supplementary question regarding the reason why they do not buy Romanian products. It would have been important to find out if this fact is motivated by personal reasons or by difficulties in finding and purchasing home country goods. The Orozco (2015) study about the Albanian community in the U.S. is representative in this respect.

Informal discussions revealed that many Romanians complain about the existing Romanian product distribution chain in Germany. They accused the limited number of shops selling Romanian products, as well as the limited range of merchandised products. In this respect, the survey's questionnaire included a question concerning improvements expected by subjects in regards to the distribution of Romanian products in Germany. Their opinions are presented in the figure below: 


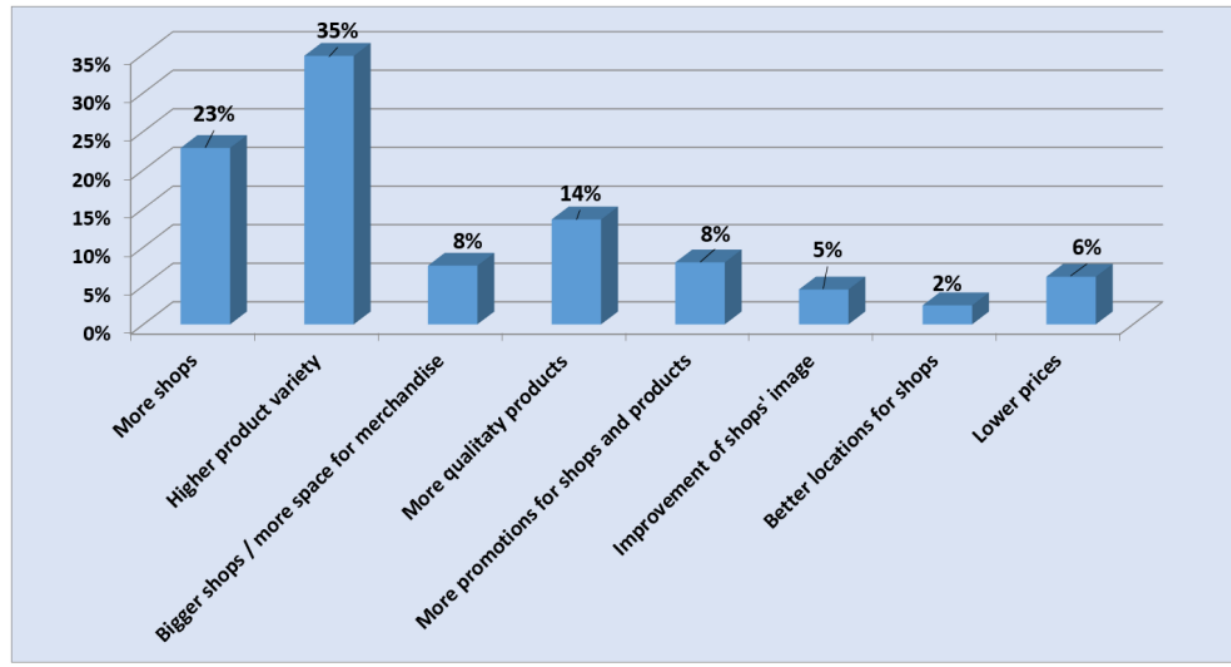

Figure 2: Subjects' expectations regarding the distribution of Romanian ethnic products in Germany

Source: Field Survey, 2017

\section{Discussion and conclusion}

The study shows that there is a significant percent of Romanian migrants in Germany, $81 \%$, who regularly buy Romanian products. Using as reference the Orozco research, the percent suggests a medium to high percent of nostalgic product consumers among Romanian residents in Germany. It would be relevant to mention that the secondary data suggests the existence of an even higher percent of nostalgic product consumers among the Romanian residents in Italy and Spain. If true, a possible explanation may lie in the fact that the Romanian diaspora in Germany is rather young compared with the Romanian diasporas in Italy and Spain. Statistics show that the number of Romanian residents in Germany significantly increased from 126,536 on December 31,2010 to 622,780 on December 31, 2017.

We may assume that the development of the Romanian product distribution chain in Germany is on course and will make progress in the next period in order to satisfy the increasing demand. The question regarding the subjects' expectations offers some suggestive clues about an existing gap between the demand and the supply of Romanian products in Germany. The subjects' answers suggest that an important category of consumers are not pleased with the existing number of stores selling Romanian products in their town or region, and they are expecting an increase in the shops' number as well as a more diversified range of products. Based on these answers we may suppose that the underdeveloped distribution of Romanian products may be one of the causes for the important percent of subjects declared as not consuming Romanian products.

Orozco's research offers an important comparison opportunity. The average monthly expense on ethnic products of 498 USD places the Romanian migrant consumer close to the Bolivian, Salvadoran, Mexican or Colombian consumer in the U.S. (Orozco 2008c: 3). 
Table 6: Expenditure of ethnic products bought in the U.S.

\begin{tabular}{|l|c|c|c|c|c|}
\hline $\begin{array}{l}\text { Country of } \\
\text { origin }\end{array}$ & $\begin{array}{c}\text { Number of } \\
\text { products bought }\end{array}$ & $\begin{array}{c}\text { Times } \\
\text { bought } \\
\text { per month }\end{array}$ & $\begin{array}{c}\text { Price paid } \\
\text { per unit } \\
(\$)\end{array}$ & $\begin{array}{c}\text { Monthly } \\
\text { expense } \\
(\mathbf{\$})\end{array}$ & $\begin{array}{c}\text { Total paid } \\
\text { per year } \\
(\$)\end{array}$ \\
\hline Honduras & 3 & 8 & 4 & 95 & 1141 \\
\hline Ethiopia & 3 & 14 & 3 & 90 & 1077 \\
\hline Philippines & 3 & 3 & 13 & 99 & 1020 \\
\hline Ghana & 3 & 7 & 3 & 77 & 919 \\
\hline Paraguay & 3 & 7 & 3 & 74 & 884 \\
\hline Dom. Rep. & 3 & 8 & 3 & 66 & 793 \\
\hline India & 4 & 4 & 4 & 58 & 694 \\
\hline Nigeria & 3 & 6 & 4 & 57 & 683 \\
\hline Colombia & 4 & 5 & 2 & 47 & 564 \\
\hline Mexico & 3 & 3 & 4 & 41 & 494 \\
\hline El Salvador & 2 & 4 & 4 & 38 & 458 \\
\hline Bolivia & 2 & 5 & 4 & 34 & 408 \\
\hline
\end{tabular}

Source: Orozco, M. (2008c: 3). Tasting Identity: Trends in Migrant Demand for Home Country Goods. Summary. U.S. Agency for International Development.

Other similarities in the motivations for buying home origin goods were revealed. For example, the majority of Romanian migrants, $47 \%$, indicate as the main reason for buying "nostalgic products" the fact that they "like them", or they "like their taste". This result is similar to the ones presented by Orozco (2008c) in the cases of the Mexican, Dominican and Nigerian communities in the U.S.

Table 7: Migrant motivations to buy ethnic products in the U.S. (percentage)

\begin{tabular}{|l|c|c|c|c|c|}
\hline $\begin{array}{c}\text { Country } \\
\text { of origin }\end{array}$ & $\begin{array}{c}\text { Continue } \\
\text { my home } \\
\text { country } \\
\text { diet }\end{array}$ & $\begin{array}{c}\text { Sense of } \\
\text { attachment } \\
\text { to home } \\
\text { country }\end{array}$ & $\begin{array}{c}\text { Product is } \\
\text { unique to my } \\
\text { home } \\
\text { country }\end{array}$ & $\begin{array}{c}\text { Quality of product } \\
\text { is higher than } \\
\text { other able } \\
\text { products }\end{array}$ & I like it \\
\hline Nigeria & 21 & 3 & 12 & 10 & 54 \\
\hline Mexico & 2 & 12 & 24 & 13 & 49 \\
\hline Dominican Rep. & 1 & 3 & 28 & 24 & 44 \\
\hline Colombia & 1 & 8 & 28 & 26 & 36 \\
\hline Philippines & 6 & 34 & 20 & 2 & 38 \\
\hline Ghana & 13 & 20 & 23 & 15 & 29 \\
\hline Ethiopia & 22 & 28 & 16 & 8 & 27 \\
\hline Bolivia & 31 & 31 & 0 & 19 & 19 \\
\hline Honduras & 16 & 27 & 16 & 22 & 18 \\
\hline Paraguay & 16 & 14 & 31 & 24 & 15 \\
\hline El Salvador & 35 & 33 & 0 & 21 & 11 \\
\hline India & 45 & 32 & 18 & 5 & 1 \\
\hline
\end{tabular}

Source: Orozco, M. (2008c: 4). Tasting Identity: Trends in Migrant Demand for Home Country Goods. Summary U.S. Agency for International Development.

Comparing the ethnic product consumption habits of Romanian migrants in Germany with those of other ethnic communities represents an important opportunity for a better understanding of the Romanian diaspora and in the same time an opportunity for observing some general features of diasporas. The significant number of similarities between Romanian migrants in Germany and other migrant communities, especially the South 
American communities in the U.S., as regards the consumption habits related to home country goods suggests the existence of a pattern in this respect among the members of different diasporas throughout the world. It is a perspective worth being considered by future research.

The research findings are also relevant for the Romanian companies, especially the ones active in the food and beverage sector, as it reveals an important demand for home country goods among the Romanian diaspora.

\section{Limitations and implications for further study}

The research has a number of evident limitations. It is obvious from the secondary data analysis, the discussions with the subjects and the range of products displayed by the visited stores in Bavaria, Germany that most of the Romanian products purchased by Romanian residents in Germany are food and beverage products. However, the questionnaire used in the survey did not include a question regarding the most frequently purchased Romanian products.Such a question included in future surveys questionnaires should reveal the predominance of the food and beverage products in the range of ethnic products available in the Romanian ethnic stores in Germany. It will also help in identifying the most frequently purchased ethnic products.

During a two-month time period a significant number of subjects, 124 , were selected and agreed to complete the questionnaire, assisted by the interviewer. However, for various reasons, there were subjects who could not answer all of the questions, resulting in gaps of data which affected the overall results of the research. Despite the fact that the survey includes a significant number of subjects, 124, selected from four different cities, another disadvantage is represented by the fact that all of the cities are located in one region of Germany, Bavaria. It would be preferable for future surveys addressing this topic to include subjects residing in different German regions.

The purpose of the current study has been to identify the main traits regarding the consumption of home origin goods among Romanian migrants in Germany. The research methodology has been adapted for this purpose. In many aspects, the current study has the traits of an exploratory research. Under these circumstances, these findings can represent a useful base for further research, which should investigate more deeply the phenomenon. A socio-demographic profile of Romanian migrants in Germany or correlations between the number of years of residence in Germany and ethnic product consumption could represent some directions for future research.

\section{Acknowledgements}

I would like to thank Prof. Alexander M. Danzer Ph.D., Mr. Carsten Feuerbaum (M.Sc.), Katholische Universität Eichstätt-Ingolstadt and the Bavarian Ministery of Education and Culture, Science and Art for their support in survey conduct, and to Faculty of Economic Sciences, University of Oradea staff for their assistance in writing and publishing this article.

\section{References}

Anghelache, C., Nita, G., C. and Badiu A. 2017. Migratia si Remitentele - modele statistico-economice utilizate in analiza impactului remitentelor in dezvolarea economica. Romanian Statistical Review. Supplement nr. 6 / 2017, [pdf] Available at: http://www.revistadestatistica.ro/supliment/wp-content/uploads/2017/06/RRSS_06_2017_A 07_RO.pdf [Accessed 23 June 2018]. 
Croitoru, A. 2013. An insight into the nature of the relationship between migration and entrepreneurship. Journal of Comparative Research in Anthropology and Sociology, Vol 4 (1), Summer 2013.2 Available: $<$ https://www.researchgate.net/publication/272395258 An insight into the nature of the relationship between migration and entrepreneurship> [Accessed 23 June 2018].

Dinu, V., Grosu, R. M., Saseanu, A.S. (2015). Romanian Immigrant Entrepreneurship: Utopia or Reality? An Overview of Entrepreneurial Manifestations of Romanian Immigrants in Andalusia, Spain. Transformations in Business \& Economics, 14 (1) (34), pp.48-64.

Drăgulin, S., D., 2012. Vingt ans de phenomena migratoire Roumain. Cogito Multidisciplinary research Journal, Iss. 03, pp. 68-83.

Dunlevy, J., A., William K. Hutchinson W. K. 1999. The Impact of Immigration on American Import Trade in the Late Nineteenth and Early Twentieth Centuries. The Journal of Economic History, 59(4), pp. 1043-1062. Published by: Cambridge University Press on behalf of the Economic History Association Stable, Available at: http://www.jstor.org/stable/2566687 [Accessed 20 January 2018].

Elo, M., 2012. Diaspora networks in international business and transnational entrepreneurship - A literature review. Center for Transnational Studies (ZenTra), 40 / 2014. Available:

https://webcache.googleusercontent.com/search?q=cache:XEWL8yvnMRAJ:https://www.r esearchgate.net/profile/Maria Elo/publication/267863088 Diaspora Networks in Internati onal Business and Transnational Entrepreneurship A Literature Review/links/55b9e1f9 08aed621de0886d4/Diaspora-Networks-in-International-Business-and-Transnational-Entre preneurship-A-Literature-Review $+\& c d=1 \& h \mid=r o \& c t=c l n k \& g l=r o \quad$ [Accessed 13 January 2018].

European Central Bank, [online] Available at: <https://www.ecb.europa.eu> [Accessed 25 August 2018].

EUROSTAT. 2018. Migration and migrant population statistics. Statistics Explained. [pdf] Available at: https://ec.europa.eu/eurostat/statistics-explained/pdfscache/1275.pdf [Accessed 31 August 2018].

Federal Statistical Office of Germany (DeStatis - Statistisches Bundesmat) [online] Available at: https://www.destatis.de/EN/Homepage.html [Accessed 23 May 2018].

Genc, M. et al. 2011. The Impact of Immigration on International Trade: A Meta-Analysis. IZA Discussion Paper, No. 6145.

Girma, S. and Yu, Z. 2000. The link between immigration and Trade Creation: What Can the Evidence from Britain Tell Us?. Centre for Research on Globalisation and Labour Markets, School of Economics, University of Nottingham, Research Paper 2000/23, [pdf] Available: https://www.nottingham.ac.uk/gep/documents/papers/2000/00-23.pdf [Accessed 20 January 2018].

Herban, D., F. 2015. How important are Remittances Flows for Romania? The USV Annals of Economics and Public Administration. 1 (22), pp. 103-110.

Hernandez, E. 2014. Finding a Home away from Home: Effects of Immigrants on Firms' Foreign Location Choice and Performance. Administrative Science Quarterly XX, (X), pp $1-36$.

Javorcik, B., S., Özden Ç., Spatareanu M., Neagu, C. 2011. Migrant Networks and Foreign Direct Investment. Journal of Development Economics, 94 (2), pp. 231-241.

Kumar, N. and Steenkamp, J.B. E.M. 2013a. Brand Breakout, How Emerging Market Brands Will Go Global. Palgrave Macmillan.

Kumar, N. and Steenkamp J.B. E.M. 2013b. Diapora Marketing. Harvard Busines Review. Available: https://hbr.org/2013/10/diaspora-marketing [Accessed 04 October 2017].

Kusum, M. 2012. Immigration and trade creation for the US: The role of immigrant occupation. Discussion Paper Series, Forschungsinstitut zur Zukunft der Arbeit, No. 7073, 
[pdf] Available: https://www.econstor.eu/bitstream/10419/69357/1/733628729.pdf [Accessed 10 February 2018].

Mehmood, A., Jamal and A., Sriram, V. 2015. Ethnic marketing, ethnic entrepreneurship and social innovation. The Routledge Companion to Ethnic Marketing, Routledge, Jamal A., Peñaloza L. and Laroche M.(Eds.), pp. $84-96$.

Newland, K. and Taylor, C. 2010. Heritage Tourism and Nostalgia Trade: A Diaspora Niche in the Development Landscape. Washington, DC: Migration Policy Institute, [pdf] Available at: https://www.migrationpolicy.org/pubs/diasporas-tradetourism.pdf [Accessed 09 June 2017].

Orozco, M. 2005a. Transnational Engagement, Remittances and their Relationship to Development in Latin America and the Caribbean. Washington, DC: Institute for the Study of International Migration, Georgetown University, July, 2005, [pdf] Available at: https://monroecollege.edu/uploadedFiles/ Site Assets/PDF/Remittances-and-Developmen t-in-Latin-A-and-CA.pdf [Accessed 16 June 2018].

Orozco, M. 2005b. Diasporas, Development and Transnational integration: Ghanaians in the U.S., U.K. and Germany. Institute for the Study of International Migration and Inter-American Dialogue, U.S. Agency for International Development, October 23, 2005, [pdf] Available at http://ww.w.thedialogue.org/PublicationFiles/Ghanaian\%20transnationalism.pdf [Accessed 14 June 2018].

Orozco, M. 2008a. Tasting Identity: Trends in Migrant Demand for Home Country Goods. MicroNOTE \#56. US Agency for International Development, [pdf] Available at: https://www.marketlinks.org/sites/marketlinks.org/files/resource/files/mN\%2056\%20Tasting \%20ldentity.pdf [Accessed 23 June 2018].

Orozco, M. 2008b. Digesting Nostalgic Trade: A Prequel to a Value Chain Approach. US Agency for International Development, [pdf] Available at: https://www.marketlinks.org/sites/marketlinks.org/files/resource/files/ML6217 breakfast 3 6 final.pdf [Accessed 10 June 2018].

Orozco, M. 2008c. Tasting Identity: Trends in Migrant Demand for Home Country Goods Summary. US Agency for International Development. [pdf] Available at: http://archive.thedialogue.org/PublicationFiles/DNA\%20Paper\%20Series\%20-\%20Tasting \%20Identity 11-18-08-Summary FINAL.pdf [Accessed 09 June 2018].

Orozco, M. 2015 The Demand for and Supply of Nostalgic Products among the Albanian-Americans: A Survey. Report commissioned by the Center for International Development at Harvard University, [pdf] Available at: https://growthlab.cid.harvard.edu/files/growthlab/files/nostalgic_trade_albanian_americans. pdf [Accessed 13 June 2018].

Sandu, D. 2010. Lumile sociale ale migrației românești în străinătate. Polirom, [pdf] Available

$<$ https://www.researchgate.net/profile/Dumitru Sandu/publication/242654606 Lumile soci ale ale migratiei romanesti in strainatate/links/55314c5a0cf27acb0dea93d0/Lumile-soci ale-ale-migratiei-romanesti-in-strainatate.pdf> [Accessed 18 June 2018].

Sandu, D. 2018. Romanian Migration Fields on the Move. Centre for Migration Studies, Faculty of Sociology and Social Work, University of Bucharest (UB). Available: https://www.researchgate.net/publication/324606088_ROMANIAN_MIGRATION_FIELDS_ ON_THE_MOVE. [Accessed 21 July 2018].

Săseanu, A.S. and Raluca Mariana Petrescu, R.M. 2011. Potential Connections between Migration and Immigrants' Food Consumption Habits. The Case of Romanian Immigrants in Andalusia, Spain. Amfiteatru Economic, XIII (Special 5), pp. 790 - 802.

Saseanu A. S., Petrescu R. M., Zgură I D. 2011. Research Concerning the Romanian Immigrants Owners of Grocery Stores with Romanian Food Products in Andalusia, Spain. "Ovidius" University Annals, Economic Sciences Series, XI (2), pp. 1175 - 1179. 
United Nations, Department of Economic and Social Affairs, Population Division, 2016. International Migration Report 2015 Highlights (ST/ESA/SER.A/375), [pdf] Available at: $<$ http://www.un.org/en/development/desa/population/migration/publications/migrationreport /docs/MigrationReport2015 Highlights.pdf [Accessed 21 July 2018].

\section{Bio-note}

Andrei Bundas is a master's student in the Faculty of Economic Sciences at the University of Oradea. His area of interest is migration and its economic implications. As an Erasmus student of the WFI - Ingolstadt School of Management, Faculty of the Catholic University of Eichstätt-Ingolstadt, he was involved in the study of the Romanian community in Bavaria, Germany. For several years, he was active in the export department of a Romanian company, with his activity closely related to the Romanian diaspora. 